\title{
WHAT MONGOLIA PRODUCES THAT THE WORLD SHOULD KNOW ABOUT? CONSUMERS' INFORMATION PROCESSING MECHANISMS
}

\section{TuUl PUREVDORJ}

University of Saint Joseph, Macao, China

\section{Susana Costa e SILVA*}

Universidade Católica Portuguesa, Porto, Portugal

\begin{abstract}
The present study attempts to understand the use of three information processing mechanisms - cognitive, affective, and normative - to assess the quality of cashmere products made in Mongolia. For attaining the above aims, semi-structured interviews were conducted to test a framework that resulted from literature reviewed on country of origin ( $\mathrm{COO}$ ) effect and information processing mechanisms. Results demonstrate that for Business-to-Business (B2B) clients, the $\mathrm{COO}$ is an extremely relevant cue to evaluate the quality of cashmere. Conversely, most of the consumers do not seem to include the $\mathrm{COO}$ effect on their information processing and base their evaluation on four distinct product-related attributes: quality, brand, social status, and price. Results are relevant for the Mongolian cashmere industry, as well as for marketers interested in understanding what drives consumers of cashmere in their buying decisions. We also understand these findings to assist in improving the image of Mongolia as one of the world's best manufacturers of cashmere.
\end{abstract}

JEL classification: M31, M38

Keywords: Information Processing Mechanisms, COO effect, Cashmere products, Mongolia, Product-related attributes.

\section{Introduction}

Mongolia is considered the second most prominent Manufacturer of raw cashmere and according to the National Statistics Office of Mongolia, in 2016 Mongolia's production of raw cashmere reached 8,900 tons, and was responsible for 30 to $35 \%$ of the world's supply of this commodity. However, the Mongolian Ministry of Foreign

\footnotetext{
* Corresponding author. Address: Católica Porto Business School, Universidade Católica Portuguesa, Rua Diogo Botelho, 1327, 4169-005 Porto, Tel: +351 2261962 00, Portugal, E-mail: ssilva@porto.ucp.pt
} 


\begin{abstract}
Affairs and Trade and United Nations Development Program Trade Policy and Human Development (2009) stated that only 10 to $15 \%$ of its fibre is used by domestic companies to manufacture products made of this material, while the rest is mainly transformed in semi-processed cashmere that is mostly exported to China, Italy, Japan, and the UK. As a result, there seems to be value in the cashmere production that has been passed to other countries. Hence, there seems to be an overall positive perception on the cashmere 'Made in' Mongolia, which is probably being neglected by its manufacturers. Moreover, even though Mongolian cashmere is one of the most desirable fibres in international markets due to its superior length and thickness (Tuvshintugs, Bumchimeg \& Erdenebulgan, 2015), the lack of products labelled as being made with Mongolian cashmere tends to hinder them from benefiting from the Country of Origin (COO) effect, which could positively affect consumers' perception about the quality of these goods (Lee, Lo, \& Enkhtuvshin, 2010). In studies, notwithstanding that the concept of $\mathrm{COO}$ has been extensively researched by academics (Dinnie, 2008), few scholars have focused their investigations on the impact that COO may have on products made in less developed countries like Mongolia; hence, this study investigates the $\mathrm{COO}$ effect on consumers' information processing mechanisms (i.e. cognitive, affective, and normative), as well as the factors that have stronger impact on consumers' perception and evaluation of cashmere products made in Mongolia. We will examine the relevance of the $\mathrm{COO}$ effect on consumer's information processing mechanisms; and the significance of product-related attributes in the process.
\end{abstract}

\title{
2. Theoretical background and model development
}

\subsection{Country of Origin: An overall perspective}

At the beginning of the 1960s, Dichter's (1962) research revealed that consumers seem to be influenced by the country where a certain product is made, leading them to accept or refuse to purchase the good depending on its origin. The first empirical study that was able to find the effect of Country of Origin (COO) on consumers' evaluation of products was developed three years later by Schooler (1965) who discovered that consumers tend to associate products with their country of origin. Moreover, the investigation showed that consumers' opinion about a product is influenced by the $\mathrm{COO}$ effect, which seems to have an impact on their buying behaviour (Schooler, 1965). Similarly, Nagashima's (1970) research findings revealed that the image, reputation, and sometimes the stereotypes that businessmen and consumers develop about a certain country tend to be attached to the products manufactured by that nation. Furthermore, the generalizations and perceptions that seem to be rooted in consumers' minds, which Nagashima (1970) associates with the concept of country image, have an impact not only on consumers' product evaluation, but also on their decision-making process (Hunjra, 2015).

Therefore, the COO effect can be defined as the influence - positive or negative - that the country of manufacture may have on consumers' information processing that involves their choices (Samiee, 2016), as well as their subsequent behaviour (Rezvani, 2012). 
However, authors like Papadopoulos (1993) considered the concept of COO to be substantially narrow, especially regarding the global production system, where products may have different provenances depending on the place where they were designed, manufactured, or even assembled. Consequently, Papadopoulos (1993) introduced a broader construct: Product-Country Image that associates the image of a given nation to the role played by the origin of the product, which acts as an extrinsic cue, and becomes part of the good's overall image.

On the other hand, depending on a country's political, economic, technological, and social environment, consumers may develop a particular attitude towards its products and brands (Ammi, 2013); thus, consumers' perception of the quality of a given product tends to be closely associated with their knowledge about the country where the product was made, and in certain cases, with the nation's level of economic development (Bertoli, 2013). Consequently, products from more developed countries generally tend to have a more positive image than those manufactured in less developed nations, which will influence consumers' perception about the quality of the goods (Apetrei, 2010). Products from less developed countries, As a result, may face some barriers and constraints regarding their entry and positioning in the international arena (Došen \& Previšić, 2001).

\section{The COO effect on Consumers' Information Processing Mechanisms}

Research regarding the way consumers perceive and evaluate a product revealed that when consumers are processing products' $\mathrm{COO}$ information they tend to rely on three mechanisms: cognitive, affective, and normative (Table 1) (Johansson, 1989; Obermiller \& Spangenberg, 1989). As a result, these three processes seem to influence consumers' perception about the overall evaluation of the products (Johansson, 1989; Obermiller \& Spangenberg, 1989; Fischer, 2017).

Table 1. Examples of Consumers' Information Processing Mechanisms

\begin{tabular}{|c|c|c|}
\hline Mechanism & Description & Major findings \\
\hline Cognitive & $\begin{array}{l}\text { COO is a cue for } \\
\text { product quality }\end{array}$ & $\begin{array}{l}\text { Country of origin is used as a "signal" for overall } \\
\text { product quality and quality attributes, such as } \\
\text { reliability and durability (Li \& Wyer, 1994; } \\
\text { Steenkamp, 1989). }\end{array}$ \\
\hline Affective & $\begin{array}{l}\text { CoO has symbolic } \\
\text { and emotional value } \\
\text { to consumers }\end{array}$ & $\begin{array}{l}\text { Country of origin is an image attribute that links } \\
\text { the product to symbolic and emotional benefits, } \\
\text { including social status and national pride } \\
\text { (Askegaard \& Ger 1998; Batra et al., 1998). }\end{array}$ \\
\hline Normative & $\begin{array}{l}\text { Consumers hold } \\
\text { social and personal } \\
\text { norms related to } \\
\text { COO }\end{array}$ & $\begin{array}{l}\text { Purchasing domestic products may be } \\
\text { regarded as a "right way of conduct", because } \\
\text { it supports the domestic economy (Shimp \& } \\
\text { Sharma, 1987). By the same token, consumers } \\
\text { may refrain from buying goods from countries } \\
\text { with objectionable activities or regimes (Smith, } \\
\text { 1990; Klein, Ettenson \& Morris, 1998)). }\end{array}$ \\
\hline
\end{tabular}


In the case of cognitive process, scholars argue that it is used as a cue, a signal, of the quality of the products (Bloemer, Brijs, \& Kasper, 2009; Fischer, 2017), even though this mechanism may also be associated with emotions, pride, status, authenticity, as well as identity or other attributes related to consumers' selfexpression (Fischer, 2017). Hence, apart from the intrinsic cues that are associated with the physical characteristics of the products, consumers may also use extrinsic cues like COO during their information processing (Veale, 2006).

Similarly, the affective mechanism seems to be closely related to consumers' emotional feeling towards a product's $\mathrm{COO}$, which can involve not only their memories about a given country, but also consumers' national and ethnic identities (Fischer, 2017). Therefore, the affective process does not tend to be based on consumers' knowledge about the products, but on their personal perception of the product's COO image (Askegaard \& Ger, 1998). Consequently, depending on the item's COO, the affective mechanism may alter consumers' information processing in a positive or negative manner (Fischer, 2017). The normative process tends to be connected to consumers' intentions towards the purchase of a product, which seem to be driven by the notion of ethnocentrism and the moral reflections that result from the cues associated with COO (Bloemer, Brijs, \& Kasper, 2009). Hence, this mechanism is closely related to consumers' norms and personal beliefs regarding the purchase of national or foreign products, and the moral issues associated with such action (Shimp \& Sharma, 1987).

In sum, the cognitive mechanism is related to consumers' knowledge about a product's $\mathrm{COO}$, the affective process is associated with the emotional value that consumers attribute to the country where the item was made, while the normative mechanism exposes consumers' norms and beliefs towards the purchase of a product from a given nation (Roth, 2008). It is important, nevertheless, to stress that apart from the COO effect, consumers' knowledge about a specific product may act as an important factor, which can affect consumers' purchasing decisions (Veale, 2006; Lee, 2009). At the same time, the characteristics of a product, such as its price, brand, physical attributes, as well as the manufacturer's guarantee can also influence consumers' decisions towards the purchase of the product (Agrawal \& Kamakura, 1999).

\section{The COO effect on consumers' evaluation of product-related attributes}

The perceived quality of a product seems to be closely associated with consumers' perception of the item's overall quality or superiority in comparison to similar products, and it is also connected to the product's main usage (Olson \& Jacoby, 1972). Moreover, consumers tend to assess the quality of a product based on its intrinsic and extrinsic cues, where the former (i.e. intrinsic) are usually associated with the physical attributes of the item, such as its design, colour, texture, and the materials used in its composition (Olson \& Jacoby, 1972). In turn, extrinsic cues are more subjective characteristics of the product like brand, price, guarantee, COO, social status (Table 2).

Research findings revealed that COO can become an important extrinsic cue for consumers when assessing the quality of a specific product, especially when they are unfamiliar with the item (Ammi, 2013), even though consumers may also use 
other extrinsic cues like price to evaluate the product's quality (Ammi, 2013). Furthermore, apart from the fact that $\mathrm{COO}$ apparently influences consumers' perception regarding the quality of a product, it may also have an impact on their attitudes, behaviours, and purchasing decision process (Ammi, 2013; Baker \& Ballington, 2002).

Table 2. Products' Extrinsic and Intrinsic Cues

\begin{tabular}{llll}
\hline Extrinsic cues - External Characteristics & \multicolumn{2}{l}{ Intrinsic cues - Physical characteristics } \\
\hline- & Country of Origin & - & Quality \\
- & Brand Name & - & Style / Design \\
- & Price & - & Texture / Material \\
$-\quad$ & Social Status & - & Product Color \\
$-\quad$ & Advertisement & & Packaging \\
\hline & Warranty & \\
\hline
\end{tabular}

\subsection{Model Development}

Based on the literature review, and especially on consumers' information processing involving cognitive, affective, and normative mechanisms, we developed a model (Figure 1) that seeks to explain the $\mathrm{COO}$ effect on the way consumers process the information about a specific type of products: cashmere goods made in Mongolia. In order to test this framework, and at the same time to understand which factors have a stronger effect on consumers' perceptions and evaluation of cashmere products manufactured in Mongolia, we chose to approach three distinct groups of respondents: products, distributors, and consumers.

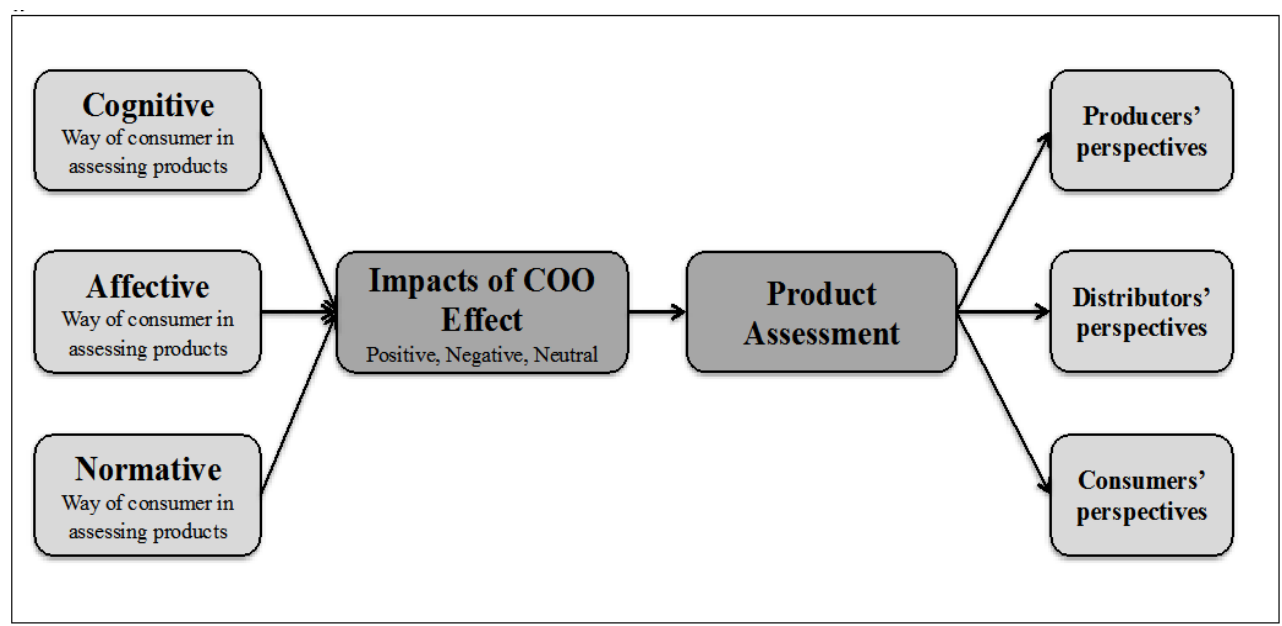

Fig. 1. Consumers' information processing mechanisms and the COO effect. 


\section{Research method}

Based on the model presented in the previous section (Figure 1), we use a case study methodology to explore the impacts of the COO effect on consumers' perception regarding cashmere products made in Mongolia. Moreover, we aimed to identify and comprehend what are the important product characteristics that may influence the consumers' information processing, along with their evaluation of this specific type of products (i.e. cashmere goods manufactured in Mongolia). Therefore, this study followed the exploratory case study method that seeks to investigate a contemporary phenomenon in depth, and within its real-life context (Yin, 2009). Using this approach, we will create multiple sources of evidence regarding to consumer's perception and evaluation of product, which would provide significant knowledge on how consumers act in response to the cashmere industry's practices in Mongolia, and develop some guidelines to improve this sector. The present exploratory case study used semi-structured interviews, as suggested by Saunders (2017), considering that these permit researchers to explore perspectives and perceptions (Ritchie, 2013), and also considering that, that these provide rich and complex information about the topic (Cavana, Delahaye, \& Sekaran, 2001). At the same time, through the use of semi-structured interviews, respondents are able to explore their own reasoning in a less restrict manner, and simultaneously to interpret their experiences, as well as to express their opinions (Ritchie, 2013). The use of the semi-structured interviewees for this study comprises both structured and unstructured characteristics with a frame of open-ended questions based on each groups of respondents and the key issues are explored and clarified by additional questions during the interviews. Hence, the semi-structured interviews were designed to test the model, and to identify which of the three mechanisms (i.e. cognitive, affective, or normative) are mostly used by consumers when processing information about cashmere products made in Mongolia.

Moreover, using their model as a theoretical framework, we chose to employ the open coding method to manually identify the original phenomenon, which allowed the production of a list of themes that were considered important for data analysis.

\section{Data collection and sample}

The use of a non-probabilistic sample technique does not intend to retrieve generalizations that can be applied to the overall population, but to develop an indepth exploration of the general phenomenon that is being studied (Creswell, 2013), where participants are chosen through a purposive sampling procedure based on their knowledge about the topic under research. The purposive sampling procedure allows authors to select participants based on their anticipated richness and relevance of information to the objectives of study (Yin, 2015). By employing the exploratory case study, the researchers are able to closely examine the data within a specific context, selecting a very limited number of respondents to be the subjects of the study (Zainal, 2007).

In this research, data was collected from semi-structured interviews of 11 key participants from three distinct groups of respondents: manufacturers, distributors, and consumers (Table 3), where the former (i.e. manufacturers and distributors) were chosen due to their knowledge, experience, and expertise in the cashmere industry, 
as well as their involvement in the different stages of the supply chain. A sample of representatives of manufacturers and distributors was to demonstrate specifications of data which from the information that consumers holding in the mind may be used to identify their position regarding to $\mathrm{COO}$ effect.

Table 3. List of Respondents

\begin{tabular}{|c|c|c|c|c|c|c|}
\hline Interviewee & Age & Gender & Nationality & Position & $\begin{array}{c}\text { Duration } \\
\text { of employment }\end{array}$ & $\begin{array}{c}\text { No. } \\
\text { employees }\end{array}$ \\
\hline \multicolumn{7}{|c|}{ Manufacturers } \\
\hline Manufacturer 1 & 54 & Female & Mongolia & CEO & 10 years & 1200 \\
\hline Manufacturer 2 & 30 & Male & Mongolia & Marketing & 7 years & 800 \\
\hline Manufacturer 3 & 29 & Female & Mongolia & $\begin{array}{l}\text { Sales } \\
\text { Manager }\end{array}$ & 8 years & 120 \\
\hline \multicolumn{7}{|c|}{ Distributors } \\
\hline Distributor 1 & 32 & Male & Sweden & Salesman & 4 years & - \\
\hline Distributor 2 & 45 & Male & Portugal & Distributer & 15 years & - \\
\hline Distributor 3 & 38 & Female & Mongolia & Manager & 10 years & - \\
\hline \multicolumn{7}{|c|}{ Consumers } \\
\hline Consumer 1 & 27 & Female & Spain & - & - & - \\
\hline Consumer 2 & 34 & Female & Russia & - & - & - \\
\hline Consumer 3 & 24 & Female & China & - & - & - \\
\hline Consumer 4 & 44 & Male & Italy & - & - & - \\
\hline Consumer 5 & 54 & Male & Portugal & - & - & - \\
\hline
\end{tabular}

Due to geographical constraints, the interviews for three respondents were conducted via Skype, four were in person, one by email, and three by telephone. Afterwards, the data from the recorded and transcribed interviews was analysed using the open coding method, as suggested by (Saldãna, 2015), in order to manually identify the initial phenomenon following the model previously developed. After the coding, data was rearranged and categorized into different sections, which allowed the identification of similarities and differences across individual information in order to create more specific data; at the end, generalization was completed to understand the different interpretations, behaviours, and needs, and so on, that exist within interviewees (Fischer, 2017).

\section{Data analysis}

The study determined the impact of COO effects on product assessment and other product related attributes under cognitive, affective and normative mechanisms. The analysis of the data retrieved from the semi-structured interviews has led us to divide the results according to each group of respondents: manufacturers, distributors, and consumers. 


\section{Manufacturers' perspectives regarding consumers' information processing mechanisms}

According to the three respondents from the manufacturers' group, there are some differences between business to business (B2B) clients and consumers, especially regarding the effect of $\mathrm{COO}$ as a quality indicator in terms of cognitive mechanism. In fact, importers of cashmere goods seem to consider the COO of these products extremely relevant, particularly if they are originally from China or Mongolia, where the latter is perceived as a manufacturer of good quality cashmere products.

As mentioned earlier, there are two countries that supply 90 to $95 \%$ of the world's raw cashmere: China and Mongolia. Since the COO effect seems to play an important role for B2B clients when assessing the quality of cashmere products, the overall image of the country apparently affects their decision to engage in a fruitful business relationship with a more reliable partner (i.e. Mongolia).

"Many of our foreign clients choose our company not only because we meet the Western standards, but also due to the fact that we always send a sample of the semi-processed cashmere to the Cashmere and Camel Hair Manufacturers Institute, so it can be tested for its quality." (Manufacturer 2)

However, in the specific case of labelling, while some clients require that the items are tagged as being made in Mongolia, others prefer that the products do not carry "Made in Mongolia" in their label. In fact, some intervenient in this process seems to understand that the effect is neutral, as final clients, in their opinion, have no product recognition, and in this case they do not believe that carrying the "made in" label will provide a special value to the product. In this case, the lack of information seems to affect the consumer's information processing mechanism. Other cases are in which the absence of an attitude towards the country leads to a preference for the "made in" absence.

"Even though some of our products are exported with the label 'Made in Mongolia', several of our clients from Canada, South Korea, and the U.S. request that the products only bear their own labels." (Manufacturer 3)

In turn, the affective process seems to be mainly related to B2B clients' perception of the prestige / reputation of the manufacturing company, as well as its national image. As a result, these clients tend to positively associate Mongolia to a country with natural resources that contribute to the breeding of excellent cashmere goats. Conversely, consumers do not seem to be emotionally attached to the product's COO. On the other hand, manufacturers apparently do not find the normative process a relevant part of consumers and B2B clients' information processing regarding the $\mathrm{COO}$ effect, since both segments do not tend to be driven by personal norms or beliefs concerning the purchase of national or foreign products.

Main players in this sector provided useful information and new insights on consumer information processing. Figures 2, 3 and 4 summarize information concerning insights from manufacturer, distributor and consumer's points of view. 


\begin{tabular}{|c|c|c|}
\hline Cognitive & Affective & Normative \\
\hline $\begin{array}{l}\checkmark \text { COO is an important cue } \\
\text { indicator for quality among B2B } \\
\text { clients } \\
\checkmark \text { Product labeled as "Made in } \\
\text { Mongolia" is irrelevant for } \\
\text { majority of B2B clients } \\
\checkmark \text { Cashmere-made final products } \\
\text { are of same quality as those } \\
\text { made in Europe. } \\
\checkmark \quad \text { Technological competence of } \\
\text { company is a substantial } \\
\text { indicator for B2B clients } \\
\checkmark \text { For consumers, quality is main } \\
\text { preference to indicate quality. } \\
\checkmark \text { Consumers who know quality } \\
\text { and superiority of cashmere } \\
\text { give minimal consideration on } \\
\text { price } \\
\checkmark \text { Majority of consumer cannot } \\
\text { indicate if the cashmere-made } \\
\text { final goods are } 100 \% \text { pure or } \\
\text { not }\end{array}$ & $\begin{array}{l}\checkmark \text { Social status of company is an } \\
\text { important information cue for } \\
\text { B2B } \\
\checkmark \text { B2B clients have a positive image } \\
\text { of Mongolia. They look at } \\
\text { Mongolia as a country of } \\
\text { cashmere. } \\
\checkmark \text { Majority of consumers are } \\
\text { emotionally appealed to } \\
\text { appearance of product's design, } \\
\text { color, and brand name. } \\
\checkmark \text { Brand represents personal identity } \\
\text { and social status of consumer }\end{array}$ & $\begin{array}{l}\checkmark \text { Many local companies are against } \\
\text { Chinese-invested companies } \\
\text { because they are the biggest } \\
\text { competitor } \\
\checkmark \text { China's investments in semi- } \\
\text { processing companies are still } \\
\text { increasing in Mongolia } \\
\checkmark \text { Increasing public awareness and } \\
\text { promoting domestic products }\end{array}$ \\
\hline
\end{tabular}

Fig. 2. Relevant insights from manufacturer's point of view

\section{Distributors' perspectives regarding consumers' information processing mechanisms}

Respondents from the distributors' group seem to perceive that most consumers are not well-informed about cashmere products' COO, which leads them not to consider it a relevant part of their information processing regarding this type of goods. This way, when product $\mathrm{COO}$ is absent or cannot be detected, consumers redirect their attention to the brand to evaluate product's quality. Besides the $\mathrm{COO}$, consumers direct their attention to the exam of other product related characteristics that might be considered in the attempt to perceive the value of the different types of cashmere made goods.

"In Europe, cashmere is associated with very timeless products, so country of origin is not a priority for consumers to evaluate this type of products." (Distributor 2, Portugal)

"In the last four years I've been working as a retailer in Sweden, and I can't recall one single case when consumers gave any attention to the cashmere products' country of origin." (Distributor 1 , Sweden) 
As regards the affective mechanism, only the Mongolian distributor (Distributor 3) recognized that after visiting Mongolia, consumers seem to develop an emotional bond to cashmere products made in this country. The previous knowledge seems then to be important in the ascertainment of a positive effect to cashmere made in Mongolia. There is room to think that this positive attitude, when existent, drives consumers to pay attention to other product related attributes.

"When foreign consumers visit our country, mostly in the Summer, and they are in contact with cashmere goods, they seem to develop some awareness of the quality of these products, which tends to lead them to perceive cashmere as being part of the identity of Mongolia." (Distributor 3, Mongolia)

Moreover, in the specific case of the Swedish distributor, the normative process may influence consumers' information processing regarding the product's $\mathrm{COO}$. In fact, even though this country supports local industries in an attempt to increase awareness and promote the products that are manufactured in Sweden, local consumers do not seem to have developed any sort of negative beliefs about cashmere products' COO. In the next figure (Figure 3) we can see that, in distributor's opinion, the second element to use when setting consumer's preferences is brand and not COO.

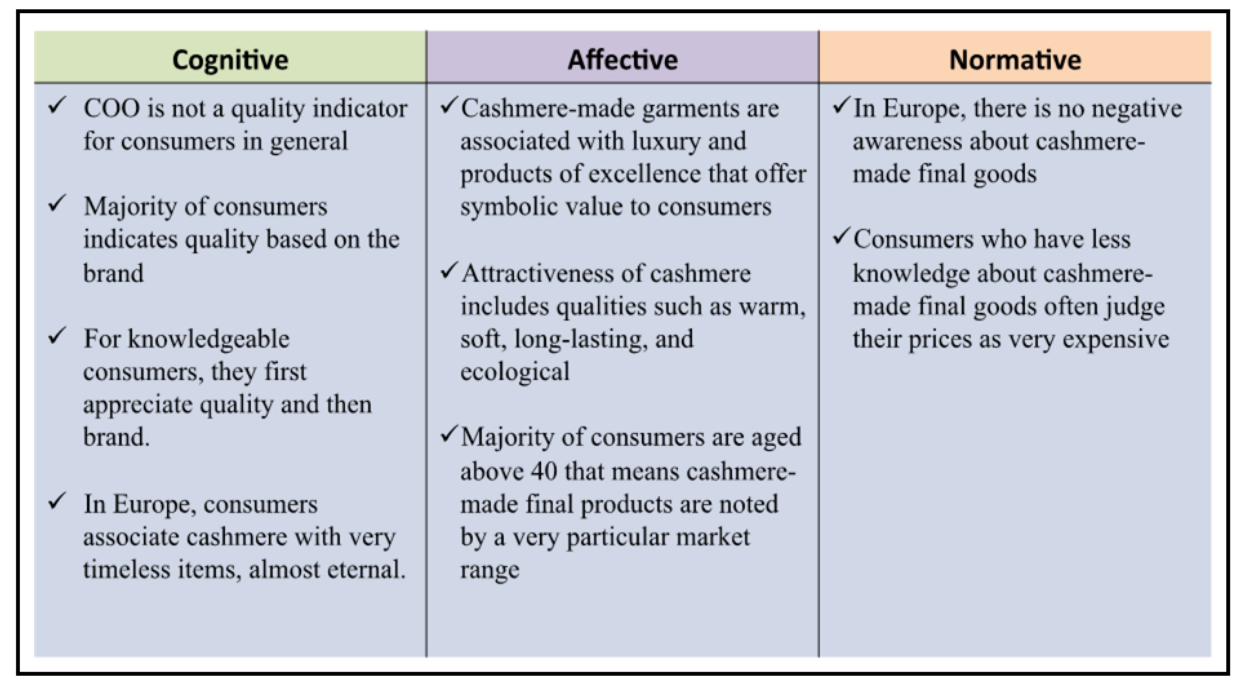

Fig. 3. Relevant insights from distributor's point of view

\section{Consumers' perspectives regarding the information processing mechanisms}

Aside from the consumer from Russia, the rest of the respondents do not seem to be aware that Mongolia is one of the leading countries that produces and manufactures cashmere products. Most of the participants tend to associate these goods' provenance with distinct parts of the globe, such as India, Australia, and the Middle East. As a result, except the Russian consumer to whom $\mathrm{COO}$ is a signal of cashmere products' quality, $\mathrm{COO}$ does not seem to play an important role on 
consumers' cognitive evaluation of this type of goods. In this case, we identified that, product $\mathrm{COO}$ - considered as a cognitive component to evaluate products - is not relevant in the decision making process. Consumers are much more concerned with the quality of the product, as we can see by the following comments.

"For me country of origin is not an important factor to evaluate the quality of cashmere products, because most of these products are made by international brands like Hermes." (Consumer 1, Spain)

"I'm not really concerned about country of origin or where cashmere products are made." (Consumer 5, Portugal)

Similarly, the one from Portugal - revealed that the affective mechanism might alter his information processing regarding cashmere products, even though in this case the respondent associated these goods with the memories of a specific purchase in Italy. In this case, results seem to indicate that consumer's product familiarity influences the way in which information is processed and stored: familiarity with the product seems to be related to product $\mathrm{COO}$.

"I bought my first overcoat in Italy 15 years ago and I still have it." (Consumer 5, Portugal)

Interestingly, the Chinese consumer's statements showed that the normative mechanism may be an important part of her information processing, since the negative image that the interviewee holds of her home country seems to lead her to purchase cashmere products made in other nations.

"I prefer to buy cashmere products that are made in other countries, instead of those that are produced in China, even if the price is higher, because I feel more satisfied with products manufactured in European countries." (Consumer 5, China)

In Figure 4 we can find the most relevant insights from consumer's point of view.

\begin{tabular}{|c|c|c|}
\hline Cognitive & Affective & Normative \\
\hline $\begin{array}{l}\checkmark \text { Majority of consumers have } \\
\text { no idea about countries that } \\
\text { produce cashmere } \\
\checkmark \text { COO is not a quality indicator } \\
\text { among consumers. } \\
\checkmark \text { Some consumers indicate } \\
\text { quality based on the brand } \\
\checkmark \text { All the consumers agreed that } \\
\text { final decision on purchasing } \\
\text { cashmere garment depend on } \\
\text { both extrinsic and intrinsic } \\
\text { information cues }\end{array}$ & $\begin{array}{l}\checkmark \text { Consumers have different } \\
\text { emotional values relating to } \\
\text { cashmere-made final goods } \\
\text { More positive feeling } \\
\text { about brand than product } \\
\text { COO } \\
\text { - Emotionally attached to } \\
\text { the design } \\
\text { - Admire cashmere-made } \\
\text { final goods due to } \\
\text { durability of product } \\
\text { - Warm and soft } \\
\checkmark \text { Cashmere is luxury good that } \\
\text { represents social status }\end{array}$ & $\begin{array}{l}\checkmark \text { Chinese consumer has negative } \\
\text { image of her own country. } \\
\checkmark \text { Personal morality is very strong } \\
\text { for some consumers. As long as } \\
\text { consumers are satisfied with } \\
\text { product, COO and brand are } \\
\text { useless information cues. } \\
\checkmark \text { Nowadays, trusting brand is } \\
\text { more than trusting product } \\
\text { COO. }\end{array}$ \\
\hline
\end{tabular}

Fig. 4. Relevant insights from distributor's point of view 


\section{Discussion}

Apart from studying the COO effect on consumers' information processing, and based on the literature review, we decided to include in this research consumers' perception and evaluation of products that seem to go beyond the $\mathrm{COO}$ effect. Moreover, by conducting semi-structured interviews to three distinct groups, the investigators were able to recognize that $\mathrm{B} 2 \mathrm{~B}$ clients and consumers have two different perspectives about the perception and evaluation of cashmere products.

\section{B2B clients' perception and evaluation of cashmere products}

The interviews conducted with manufacturers showed that brand and design do not seem to influence B2B clients' evaluation of cashmere products, which is more than understandable in the B2B context where clients use Mongolian companies to manufacture their previously designed items. However, the reputation / prestige of the company is apparently a relevant cue for B2B clients, which tends to be associated with the firm's technological capability and product quality. Therefore, as a direct consequence of B2B clients' concern for product quality, the manufacturers' technological capabilities tend to be pointed as an important factor that may affect the supply chain, since the technological competencies of the firms have a direct impact on their clients' confidence, the quality of products, the lead-times, and profitability.

\section{Consumers' perception and evaluation of cashmere products}

According to the data analysis of the interviews with distributors and consumers, we found that the COO of cashmere products does not seem to be considered an important cue for consumers when they evaluate the goods. In fact, consumers tend to mainly base their evaluation of this kind of products on four distinct signals: quality, brand, social status, and price. Moreover, based on their expectations and personal identities, consumers apparently are not emotionally attached to the product's COO.

Interestingly, respondents from the distributors' group seem to perceive that consumers of cashmere products attribute more relevance to the quality of these goods, placing less importance on extrinsic cues like brand, the origin of the products, the design, or even the price.

"Consumers who purchase cashmere products are usually wellinformed people that base their evaluation of these products mainly on the quality of the garments." (Distributor 2, Portugal)

Hence, the quality of a cashmere product seems to be a primary cue for consumers to evaluate the item, while $\mathrm{COO}$ as a quality indicator tends to represent a minor consideration for them. On the other hand, the brand is apparently also an important hint, since consumers tend to assess the quality of the item using its brand as a cue.

"I believe that the brand is a symbol that represents everything about the product, especially its quality." (Consumer 4, Italy) 
"For me the brand is a quality indicator and it represents everything about the product." (Consumer 1, Spain)

However, when in the presence of the product, consumers tend to judge its quality through touch because they can feel the material and its texture. In turn, consumers who are considered as well-informed regarding cashmere products and know about the superiority of cashmere as a warm, soft, long lasting, and ecologic material apparently evaluate those items in accordance to their quality and brand, while disregarding the price. Therefore, apart from quality per se, brand is perceived as an important indicator of the quality of the good.

At the same time, Western and Mongolian consumers tend to associate cashmere products with the idea of luxury and excellence, which seem to offer a symbolic value to consumers and a way for them to show their social status.

"For Mongolian consumers, cashmere garments represent somehow their social class, and so they are willing to buy these products especially to wear in distinctive occasions like New Year's Eve or the Lunar New Year." (Distributor 3, Mongolia)

Additionally, while some consumers seem to be more concerned about the prestige of the retailer that sells high quality cashmere products, the Russian consumer claimed that design plays a very important role in her evaluation of this kind of items.

\section{Conclusions}

This research was based on a theoretical framework developed by we, which attempted to understand the $\mathrm{COO}$ effect on the three information processing mechanisms: cognitive, affective, and normative. The analysis of the data obtained through semi-structured interviews of three distinct groups - manufacturers, distributors, and consumers - revealed that most consumers do not seem to be able to identify the main countries that produce and manufacture cashmere products. This finding showed that apparently $\mathrm{COO}$ is not the main indicator of the product's quality, and consequently does not seem to have an impact on consumers' information processing. In fact, even within the segment of well-informed consumers who seem to know about cashmere and its properties (viz. warmth, softness, durability) the $\mathrm{COO}$ effect does not influence their information processing nor their overall evaluation of the product, which is in line with Veale, (2006) and Lee, (2009) research findings. Moreover, when consumers evaluate cashmere products, they tend to rely on four specific cues: quality, brand, social status, and price.

On the other hand, research findings concerning the use of the cognitive mechanism among B2B clients revealed that they tend to consider the products' $\mathrm{COO}$ as an important cue to evaluate cashmere goods' quality, which is in line with previous results from Bloemer, Brijs, \& Kasper, (2009) and Fischer, (2017). In turn, the affective process regarding B2B clients' information processing seems to be mainly influenced by the positive image that these consumers have of Mongolia, which is similar to the findings from Hunjra (2015), Ammi (2013), Lee (2009), Veale (2006), Nagashima (1970) and Papadopoulos (1993). Interestingly, the normative mechanism does not seem to be important for B2B clients neither for most consumers' information processing. 


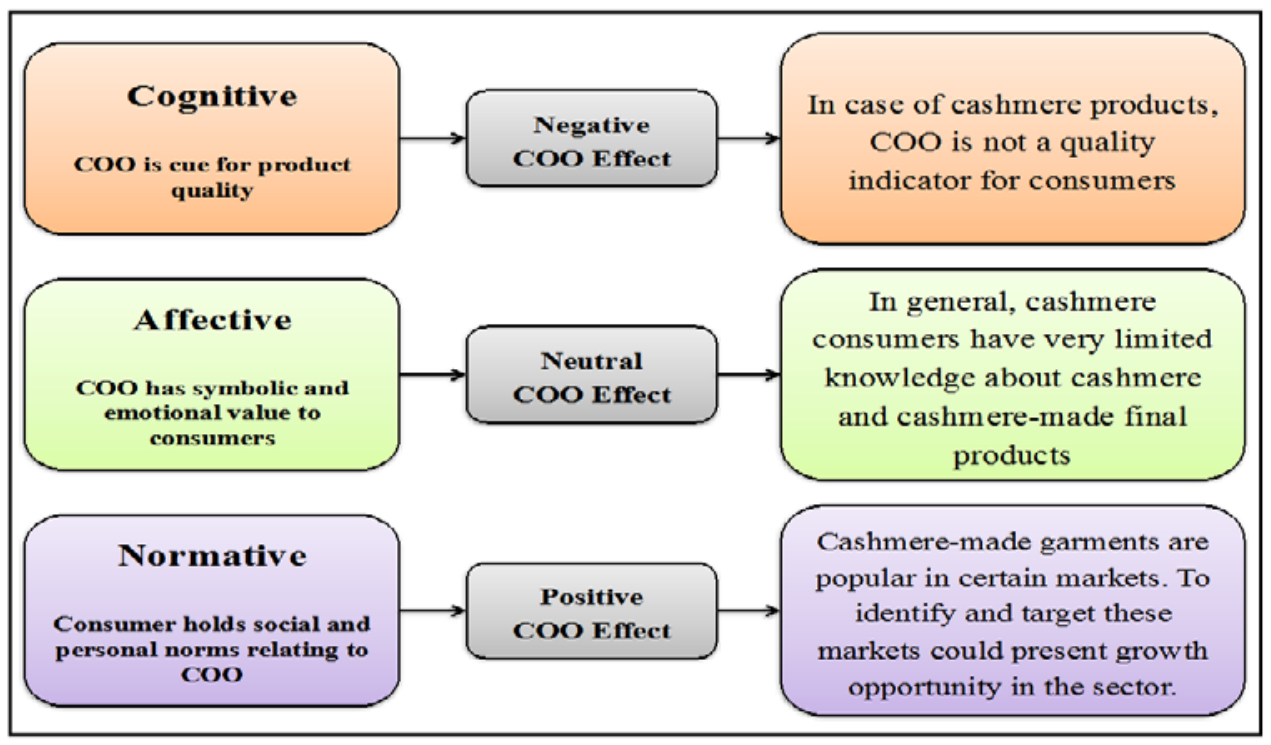

Fig. 5. Results of COO Effects on Consumer Information Processing Methods

\section{Managerial implications}

In recent years, there has been an increasing demand for cashmere goods, which can be considered an important opportunity for the cashmere industry in countries like Mongolia - the second largest supplier of raw cashmere - to increase consumers' awareness in international markets about the uniqueness of Mongolian cashmere and the goods produced with this fibre. Moreover, according to the results of this study, it seems that the Mongolian cashmere sector may also benefit from the $\mathrm{COO}$ effect, and the rising criticisms and negative feelings of consumers who perceive Chinese products in general to be of lower quality. Nevertheless, despite B2B clients' positive image of Mongolia and the quality of its cashmere products, most of them do not wish to label their products as "Made in Mongolia". As a result, by accepting this requirement most Mongolian cashmere manufacturers do not seem to be contributing to the future prosperity of this industry.

At the same time, since many consumers are unaware of the origin of cashmere, the existing Mongolian players within this industry, as well as government agencies, should develop business and marketing strategies to promote the country as one of the best manufacturers of cashmere. This will improve the image of Mongolia in international markets, especially among consumers from other countries.

This study also revealed that consumers and B2B clients evaluate cashmere products based on the quality of its material, which stresses the need for Mongolian manufacturing companies to enhance their technological competencies in order to achieve a competitive advantage that will distinguish them from their foreign competitors. Therefore, through the support of Mongolian Wool and Cashmere Association, as well as government agencies, other business associations, and home and host investors, local companies would be able to better compete in the international arena. 
On the other hand, the research findings showed that brands are becoming increasingly relevant for consumers, mainly because they tend to represent consumers' personal identity and social status, while at the same time they are used as a cue to classify the quality of the products. However, consumers do not seem to be informed about the existence of Mongolian brands specialized in the production of cashmere goods. The Mongolian cashmere industry, therefore, should develop a branding project or embrace the 'Mongolia Noble Fibre' project to successfully market and implement their brands in specific target markets, mainly in those where consumers perceive cashmere products as luxury goods because of the excellence of the material.

\section{Limitations and further research}

This study was focused on the effect of $\mathrm{COO}$ on consumers' information processing mechanisms, as well as on their perception and evaluation of cashmere products. However, in order to collect in-depth information from respondents of two main players involved in the Mongolian cashmere industry (i.e. manufacturers and distributors), as well as consumers, the size of the sample became limited, hindering the researchers from reaching theoretical saturation. At the same time, it is important to stress that the model developed in this study has not been validated in different countries, a situation that can be considered a limitation but also as an avenue for further research. In fact, one may argue that based on the interviews conducted to consumers from distinct nations, a cross-cultural study using this framework may reveal different results.

Consequently, we strongly recommend that further research shall be conducted in distinct and disparate countries, which will permit scholars to better assess the impact of national identity, norms, and beliefs in consumers' information processing regarding a specific product from a very particular country: cashmere goods made in Mongolia. Moreover, further investigation may also be focused on the effect that country image can have on cashmere products, and develop some hypotheses that could be tested using a quantitative method. Finally, future research might centre its focus on intrinsic and extrinsic information cues in order to better comprehend the main product-related attributes used by well-informed consumers when evaluating cashmere goods.

\section{References}

Agrawal, J., Kamakura, W. A. (1999). Country of origin: A competitive advantage? International Journal of Research in Marketing, 16(4): 255-267. http://doi.org/10.1016/S0167-8116(99)00017-8

Ammi, C. (2013) Global Consumer Behavior, John Wiley Sons. ISBN 13: 978-1905209-63-7.

Apetrei, A., Petrusca, C. (2010). Country-of-Origin Effect in International Trade. Timisoara Journal of Economics, 3, 4 (12): 271-276.

Askegaard, S., Ger, G. (1998). Product-Country Images: Towards a Contextualized Approach. In B. G. Englis A. Olofsson (Eds.), European Advances in Consumer Research, 3. 50-58. Provo, UT: Association for Consumer Research.

Baker, M. J., Ballington, L. (2002). Country of origin as a source of competitive advantage. Journal of Strategic Marketing, 10(2):157-168. http://doi.org/10.1080/09652540210125297

Bertoli, G. (2013). International marketing and the country of origin effect: the global impact of'made in Italy', Edward Elgar Publishing. 
Bloemer, J., Brijs, K., Kasper, H. (2009). The CoO-ELM model: A theoretical framework for the cognitive processes underlying country of origin-effects. European Journal of Marketing, 43(1/2): 62-89. http://doi.org/10.1108/MBE-092016-0047

Cavana, R. Y., Delahaye, B. L., Sekaran, U. (2001). Applied Business Research: Qualitative and Quantitative Methods. John Wiley Sons Australia.

Creswell, J. W. (2013). Research Design: Qualitative, Quantitative, and Mixed Methods Approaches (4th ed.). Thousand Oaks, CA: SAGE Publications, Inc.

Dichter, E. (1962). The World Customer. Harvard Business Review, 40(4): 113-122. http://doi.org/10.1002/tie.5060040415

Dinnie, K. (2008). Nation Branding: Concepts, Issues, Practice. ButterworthHeinemann (1st ed.). Oxford: Elsevier Ltd. http://doi.org/10.1017/CBO9781107415324.004

Došen, Đ. O., Previšić, J. (2001). Country-Of-Origin Image and Internationalization of Business Activities. In Kongres CROMAR-a Hrvatske (pp. 101-106). ZagrebPula.

Fischer, P. M., Zeugner-Roth, K. P. (2017). Disentangling country-of-origin effects: The interplay of product ethnicity, national identity, and consumer ethnocentrism. Marketing Letters, 28,(2): 189-204.

Hunjra, A. I., Kiran, S., Khalid, B. (2015). Relationship between Country of Origin Image, Product Knowledge, Product Involvement, and Purchase Intention. Bulletin of Business and Economics (BBE), 4, 1. 48-62.

Johansson, J. K. (1989). Determinants and Effects of the Use of "Made in" Labels. International Marketing Review, 6(1): 47-58. http://doi.org/10.1108/EUM0000000001502

Lee, J. K., Lee, W.-N. (2009). Country-of-Origin Effects on Consumer Product Evaluation and Purchase Intention: The Role of Objective Versus Subjective Knowledge. Journal of International Consumer Marketing, 21(2): 137-151. http://doi.org/10.1080/08961530802153722

Lee, Y.-H., Lo, H.-C., Enkhtuvshin, E. (2010). A Study of Value Delivery System in Mongolian Cashmere Industry: From Brand Equity Perspective. Internatonal Journal of Reliability and Quality Performance, 2(2): 107-118.

Mongolian Ministry of Foreign Affairs and Trade and United Nations Development Program Trade Policy and Human Development in Mongolia (2009), Ulaanbaatar.

Nagashima, A. (1970). A Comparison of Japanese and U.S. Attitudes Toward Foreign Products. Journal of Marketing, 34(1): 68-74. http://doi.org/10.2307/1250298

National Statistics Office of Mongolia (2016). Mongolian Statistical Information Service. Ulaanbaatar.

Obermiller, C., Spangenberg, E. (1989). Exploring the Effects of Country of Origin Labels: An Information Processing Framework. Advances in Consumer Research, 16(1): 454-459.

Olson, J. C., Jacoby, J. (1972). Cue Utilization in the Quality Perception Process. In M. Venkatesan (Ed.), Proceedings of the Third Annual Conference of the of the Association for Consumer Research: 167-179. Chicago, IL: Association for Consumer Research. http://doi.org/10.1108/eb026082

Papadopoulos, N. (1993). What Product and Country Images Are and Are Not. In N. Papadopoulos L. A. Heslop (Eds.), Product-Country Images: Impact and Role in International Marketing: 3-38. New York, NY: The Haworth Press, Inc. 
Rezvani, S., Shenyari, G., Dehkordi, G. J., Salehi, M., Nahid, N., Soleimani, S. (2012). Country of origin: A study over perspective of intrinsic and extrinsic cues on consumerspurchase decision. Business Management Dynamics, 1(11): 68-75.

Ritchie, J., Lewis, J., Nicholls, C. M., Ormston, R. (Eds.). (2013). Qualitative research practice: A guide for social science students and researchers. Sage.

Roth, K. P. Z., Diamantopoulos, A., Montesinos, M. Á. (2008). Home country image, country brand equity and consumers' product preferences: an empirical study. Management International Review, 48(5): 577-602.

Saunders, M. N. K., Lewis, P., (2017), Doing Research in Business Management: An Essential Guide to Planning Your ProjectPearson, Harlow. ISBN 9780273726418

Samiee, S., Leonidou, L. C., Aykol, B., Stöttinger, B., Christodoulides, P. (2016). Fifty Years of Empirical Research on Country-of-Origin Effects on Consumer Behavior: A Meta-Analysis. Rediscovering the Essentiality of Marketing. 505-510. Springer, Cham.

Saldaña, J. (2015). The Coding Manual for Qualitative Researchers. Sage Publications: Thousand Oaks, CA.

Schooler, R. D. (1965). Product Bias in the Central American Common Market. Journal of Marketing Research, 4: 394-397. http://doi.org/10.2307/3149486

Shimp, T. A., Sharma, S. (1987). Consumer Ethnocentrism: Construction and Validation of the CETSCALE. Journal of Marketing Research, 24(3): 280-289. http://doi.org/10.2307/3151638

Tuvshintugs, B., Bumchimeg, G., Erdenebulgan, D. (2015). Increasing Competitiveness of Agricultural Sector and Local People's Living Standard. In C. B. o. Mongolia (Ed.), pp. 567-654. Ulaanbaatar: Economic Research Institute.

Veale, R., Quester, P., Karunaratna, A. (2006, July). The role of intrinsic (sensory) cues and the extrinsic cues of country of origin and price on food product evaluation. In 3rd International Wine Business and Marketing Research Conference, Refereed Paper. Montpellier (pp. 6-8).

Yin, R. K. (2009). Case Study Research: Design and Methods (4th ed.). Thousand Oaks, CA: SAGE Publications, Inc.

Yin, R. K. (2015). Qualitative research from start to finish. Guilford Publications: 87107

Zainal, Z. (2007). Case Study as a Research Method. Jurnal Kemanusiaan, 5(1): 16. 